treading so delicately in the past few dramatic weeks. Solidarity, which began life as a trade union representing shipyard workers in Gdansk, and which has been illegal for much of its time, has shown all the signs of not wishing to form Poland's next government. It has been forced into accepting what many regard as a poisoned chalice (but it is not) by the failure of the Polish Communist Party to do so, which is in turn a consequence of the unwillingness of the Polish parliament (called the Sejm) to accept the arrangements proposed. That circumstance will itself surprise many in the West with an over-simple view of how the governments of Eastern Europe are organized. Although the Sejm may have been newly legitimized by last June's semi-free elections, it is at least a parliament that, on this occasion, has shown independence.

Luckily, everybody in Poland seems fully aware of the difficulties the developments of the past week have created for the other members of the Warsaw Pact, the Soviet Union included. In the real world, Mazowiecki cannot risk signs of wishing to leave the Eastern bloc without bringing down not only himself but also Mr Mikhail Gorbachev. The practical problem that he faces is whether he can win enough freedom to deal with Poland's pressing economic problems within a framework in which his motives will be deeply suspect. A firm assurance of indefinite devotion to Comecon, Eastern Europe's less democratic version of the Europen Community, is a necessary precondition of survival.

What, in the circunmstances, can people elsewhere do? The conventional view is that there is little room for manoeuvre. But that is what governments say. Offers of large amounts of credit to help with Poland's economic difficulties could easily become, in a few months or years, unpaid loans to a Polish government of quite a different complexion. Even so, there is a case for much more generosity than has been offered so far, if only to sustain hope during the harsh winter that lies ahead. But this is also an unprecedented time, when an apparently sovereign state appears openly to acknowledge that it is at a loss to know how to get out of the mess in which it finds itself. These may be circumstances in which the intellectual community in the West is more able to respond imaginatively than Western governments. A decade ago, the Brandt Commission made some constructive suggestions about the place of developing countries in the modern world, and had an important influence on public policy. Has the time come for the equivalent of a Brandt Commission for Eastern Europe?

\section{Funny money}

British ambitions to find a better convertible currency than the European Commission's await fulfilment.

WESTERN Europe needs to invent some kind of currency that can be used in all 12 member countries of the European Community by the end of 1992, but has not yet agreed how that should be done.

More precisely, the European Commission last year proposed that the European Currency Unit (ECU) should become a common currency, and that there should a Central Bank to manage its affairs, but the British government objected at June's summit meeting in Lisbon, since when West Germany has been having second thoughts. But the British government's promise to devise an alternative scheme has not yet lived up to realistic expectations, at least to judge from the British Treasury's whispered information at the weekend.

That there are serious objections to the Commission's proposals cannot be denied. Much would depend on the degree of independence enjoyed by the proposed Central Bank. If, for example, it had a large measure of autonomy, as does the Federal Reserve Bank in the United States or the Bundesbank in West Germany, there would be endless complaints from member governments that the bank was following over-conservative (or over-open) policies. If, on the other hand, the bank were politically controlled, there would be endless squabbling among the members about the correct policy to be followed. European hardliners say, with some justice, that such difficulties are inseparable from the goal of economic unity.

The British government's alternative has the merit of being imaginative, even intriguing. The principle is that existing national currencies should be allowed to compete with each other in the market places in which goods of various kinds are traded for banknotes of different denominations, but that all European currencies should simultaneously be legal tender everywhere. The argument is that national prestige would persuade governments to manage their currencies in such a way that they were considered sound, and that the soundest currency would eventually prevail.

But that is an over-sanguine view. While sellers of goods would have an interest in being paid in the currency most likely to keep its value from one day to the next, purchasers would have exactly the opposite interest. A kind of Gresham's Law would apply.

Quite apart from the horrendous difficulties arising under the British government's proposals when people from different parts of Europe sought to buy cups of coffee and other trivial goods in their national currencies, there are bound to be serious objections to any scheme that tempts either party to a commercial bargain to argue about the currency as well as the price. And would banks as well as traders be required to convert one currency into another without charge, which would be equitable in the circumstances? But there are merits of flexibility in the British proposals. The best compromise would be simultaneously to make the ECU and individual national currencies legal tender everywhere, thus allowing those who buy and sell things in Western Europe to deliver a vote of confidence in their own governments' conduct of economic affairs whenever they go into a shop. In the last resort, that would also be a constraint on the conduct of the otherwise inevitable European Central Bank.

NATURE · VOL 340 - 24 AUGUST 1989 